\title{
Teacher Gender and Attitude of Primary School Pupils to Schooling in Uyo Metropolis, Akwa Ibom State, Nigeria
}

\author{
Dr. Cornelius C. Okoro*, Dr. Christopher S. Uwah \\ Department of Educational Foundations, Guidance and Counselling, Faculty of Education, University of Uyo, Uyo, Nigeria \\ * Corresponding Author: cornokoro@yahoo.com
}

Copyright (C) 2013 Horizon Research Publishing All rights reserved.

\begin{abstract}
This study assessed the influence of teacher gender on the attitude of primary school pupils to schooling in Uyo Metropolis. Four research questions and four hypotheses were generated to direct the conduct of the study. A sample of 400 pupils was drawn from a population of 1400 primary five pupils using the multistage random sampling technique. The ex-post-facto research design was adopted for the study and the research instrument used was the Pupil's Attitude to Schooling Questionnaire (PASQ) designed by the researchers. The results showed that teacher gender has significant influence on the attitude of pupils to schooling. On the basis of the results, recommendations were made with emphasis on training and employing more males as primary school teachers to counter the current gender imbalance in the profession.
\end{abstract}

Keywords Teacher Gender, Pupil Gender, Attitude to Schooling, Primary School, Demographic Differences

\section{Introduction}

It is generally believed that a person's attitude towards a person or thing has a direct bearing on the person's reaction to the person or thing. One would infer from this that an individual's attitude affects his behaviour or performance. In fact, findings from a number of studies [1] indicate that attitude is one of the determinants of academic performance. But findings from a study like that of Kinniard [12] indicated no clear relationship between a student having a positive attitude towards his/her academic setting and achieving academic success in the classroom. Manoah, Indoshi and Othuon [18] pointed out that there was research evidence showing that students' high performance in mathematics was not necessarily positively associated with their attitudes about mathematics and mathematics learning. They cited results of the Third International Mathematics and Science Study (TIMSS) that had been presented by Mullis [19] as revealing that while Japanese students over-performed students from many other countries in mathematics, their attitudes towards mathematics were relatively negative. In fact, many psychologists are of the view that there is no direct influence of attitude on behaviour devoid of other intervening variables.

Although many psychologists have disputed the direct influence of attitude on behaviour, some of them have, however, argued that attitudes are useful in the sense that they give people a simplified and practical guide for appropriate behaviour [11]. Some psychologists have also claimed that while attitudes sometimes influence behaviour, it is our behaviour that sometimes shapes our attitudes [9]. Johnson [11] stated that some attitudes help students to function effectively in school while others interfere with school life and that many educational psychologists believe it is far more important to promote positive attitudes in students than to ensure that they master verbal information, intellectual skills, cognitive strategies, or motor skills.

Results of many studies in the sciences as well as in mathematics have indicated a strong relationship between students' attitude and their academic performance [2, 4-6, 20]. In his study, Tandoc [23] found a high degree of relationship between attitudes and performance in a mathematics diagnostic test. He went further to reason that an improvement in the students' liking for mathematics which means strengthening their positive attitude towards it leads to an improvement in their performance in mathematics. Liddell and Davidson [16] found that students performed better on those skills they valued and that that might be influenced by underlying motivation to master the skills. In contrast, they also found that students' confidence in performing a skill was not related to their assessed performance and concluded that using confidence as a performance measure might misrepresent the quality of learning being assessed. Amoo [3] was of the opinion that attitudes play a major role in the comprehensibility of mathematical concepts. According to him, when an attitude is favourable or positive, it enhances active performance that leads to success. On the other hand, when it is unfavourable or negative, it is often reflected by an individual's lack of interest and non-participation in an activity. Amoo and Rahman [4] claimed that the relationship between attitudes and performance is the consequence of a reciprocal influence, 
in that attitudes affect achievement and achievement in turn affects attitudes. Gibbons, Kimmel and O'Shea [10] opined that students' attitudes about the value of learning science may be considered as both input and outcome variables because their attitudes towards the subject can be related to educational achievement in ways that reinforce higher or lower performance. This means that students who do well in a subject generally have more positive attitudes towards that subject and those who have negative attitude tend to perform poorly in such subjects.

Concerns over the influence of attitude on students' performance have in recent times shifted and inspired research into the forces behind attitude in itself. The general assumption is that an understanding of the foundational influencers of attitude will on the one hand give more understanding to just how attitude influences performance and on the other hand explain the observed discrepancies in the outcomes of researches on attitude and performance in literature. This inspiration led the current research to focus on a rather disturbing local phenomenon in the school system - the discrepancy in the proportion of male and female teachers, especially in the primary schools. In Uyo metropolis, specifically, statistics showed that male teachers constitute only about $13.3 \%$ while female teachers constitute about $86.87 \%$ [22].

This research should however be of interest to scholars around the globe because this phenomenon might actually be a global problem in education. For instance, Smith [21] alerted that the diminishing presence of male teachers was a global issue and that the proportion of men within teaching ranks was declining significantly. He quoted figures from Nelson (2003), NEA (2003), Education Queensland (2002), Commonwealth of Australia (2002), and Queensland Catholic Education Commission (2002) to illustrate the deplorable condition of gender imbalance among primary school teachers, especially within Australia. In Nigeria generally, the picture has not been different. The female teachers have been observed to outnumber their male counterparts in schools in almost all the parts of the country.

Citing the American Association of University Women (1992), Dee [7] corroborates that the gender gaps in school achievement is a prominent policy concern. The author further submitted two general ways that the demographic mismatches/matches between pupils and teachers could influence the educational outcomes of pupils: (1) "passive teacher effects", triggered by a teacher's gender identity and not by explicit teacher behaviour, and (2) "active teacher effects", deriving from innocuous biases in teachers' expectations of and interactions with pupils of dissimilar demographic traits. Furthering on the first influence, the author maintains that "role-model effects", resulting from the presence of a demographically similar teacher increases a pupil's academic motivation and expectations. Conversely, "stereotype threat" resulting from the presence of a demographically dissimilar teacher (e.g., male pupils with female teachers) generates in the pupils anxiety about stereotypic treatment and inhibits the pupils' academic identification and subsequent achievement. Current empirical knowledge on whether any of these sorts of effects exist, though limited, is generally supportive.

Although results of studies on the influence of teacher's gender on the child's academic performance have been inconclusive, some authorities cited by Smith [21] had claimed that there was a strong relationship between the gender of the teacher and the academic performance of the child. Krieg [13] reported that a number of findings had indicated that teacher and student genders were correlated with test outcomes.

On the basis of the findings highlighted in this discussion and the fact that attitude has been seen to be of utmost importance in education, a related issue that would interest educators is whether a relationship exists between the attitude of the learner and the gender of the teacher. Mallam [17], in his study, found a significant difference between the attitude towards mathematics of female students taught by male teachers and of female students taught by female teachers. The results by Lee and Lockheed [14] indicated that a more positive attitude towards mathematics was demonstrated by female students taught by female teachers. Li [15] also stated that substantial evidence had suggested that when a teacher-student gender interaction with respect to student rating of teachers was present, most often it appeared to reflect a same-gender preference. After an elaborate review of literature, $\mathrm{Li}$, however, concluded that the issue of whether teacher gender affected student rating behaviours remained open to debate since some studies had shown little or no evidence of gender interaction, while others had demonstrated evidence of variables on which students had rated teachers of the opposite gender more highly or had preferred the teachers of the same gender. Since, as claimed by Li, the issue of whether teacher gender affected students' attitude to schooling in general remained open to debate, these authors thought it worthwhile to carry out this study to ascertain whether the gender of the teacher will impact on the attitude of primary school pupils in Uyo metropolis. This study therefore attempted to examine the influence of teacher gender on the attitude of primary school pupils to schooling in Uyo metropolis.

\section{Research Questions}

The following research questions were formulated to direct the conduct of the study:

1. Do boys taught by male teachers have more positive attitude to schooling than boys taught by female teachers?

2. Do girls taught by male teacher have more positive attitude to schooling than girls taught by female teachers?

3. Do boys taught by male teachers have more positive attitude to schooling than girls taught by male teachers?

4. Do boys taught by female teachers have more positive attitude to schooling than girls taught by female teachers?

\section{Hypotheses}

The following null hypotheses were generated from the research questions: 
Ho 1. There is no significant difference between the attitude of boys taught by male teachers and that of boys taught by female teachers.

Ho 2. There is no significant difference between the attitude of girls taught by male teachers and that of girls taught by female teachers.

Ho 3. There is no significant difference between the attitude of boys taught by male teachers and that of girls taught by male teachers.

Ho 4. There is no significant difference between the attitude of boys taught by female teachers and that of girls taught by female teachers.

\section{Research Method}

Area of Study: The study was conducted in Uyo metropolis of Akwa Ibom State, Nigeria.

Population, Sample and Sampling Technique: The population for the study consisted of all pupils in the fifth grade in Uyo metropolis. There were about 1400 grade five pupils in all the public primary schools within the metropolis at the time of the study [22]. From this population, a sample of 400 pupils was drawn for the study through multistage random sampling technique. The sample distribution comprised 100 male pupils taught by male teachers, 100 male pupils taught by female teachers, 100 female pupils taught by female teachers, and 100 female pupils taught by male teachers.

Research Design: The study utilised the ex-post-facto survey design. This design was deemed more appropriate because the research was intended to examine the supposedly existent influence of teacher gender on pupil's attitude to schooling. This is a phenomenon over which the researchers had no control.

Instrumentation: The instrument used for the study was the Pupils' Attitude to Schooling Questionnaire (PASQ), designed by the researchers. The instrument had three items capturing specific demographic characteristics of the pupils and a scale of ten items indexing the pupils' attitude to schooling - school attendance and participation in school activities and classwork. The instrument had a Cronbach's Alpha reliability coefficient of .733.

Method of Data Analysis: The data extracted from the questionnaire as administered on the sample were collated and analysed using student t-test. The calculated t-statistics were the basis for hypotheses testing in the study. All the hypotheses were tested at $\mathrm{p}<.05$ level of significance.

Results: The data obtained from the field survey were analysed using student $t$-test for the purpose of hypotheses testing. The results obtained are here presented as they correspond to each of the four hypotheses in the study.

The result of data analysis presented in Table 1 led to the rejection of Hypothesis One based on the decision rule. It would be observed, from the analysis in Table 1, that the calculated t-value of 7.78 is greater than the critical t-value of 1.97 at .05 level of significance. A closer look at the details of the result in Table 1 shows that male pupils taught by male teachers scored an average of 32.96 on the PASQ. This was much higher than the mean score of male pupils taught by female teacher (27.76) in the same population. This means that the difference in the attitudes of boys taught by male teachers and that of boys taught by female teachers is significant. This implies that teacher gender significantly influences the attitude of male pupils to schooling.

Data analysis presented in Table 2 shows that the calculated t-value of 7.27 is greater than the critical t-value of 1.97 at .05 level of significance. Useful details of the analysed data show that girls taught by male teachers scored an average of 33.07 on the PASQ. This was much higher than the mean score of girls taught by female teachers who scored an average of 27.95 on the PASQ. This led to the rejection of Hypothesis Two based on the decision rule. This result shows that the difference in the attitudes of girls taught by male teachers and that of girls taught by female teachers is significant. It could thus be concluded that teacher gender significantly influences the attitude of girl pupils to schooling.

The analysis of research data showed no significant difference in the attitude of boys taught by male teachers and the attitude of girls taught by male teachers as the calculated value of the t-statistics (0.16) was less than the critical value (1.97) at p.<.05. Thus, Hypothesis Three was upheld. Details of the analysis show that boys taught by male teachers scored an average of 32.96 on the PASQ whilst girls taught by male teachers scored and average of 33.07 on the PASQ. Were both mean scores rounded to the nearest whole number, it would be seen that both boys and girls taught by male teachers had the same average score of 33 on the PASQ.

Ho 1. There is no significant difference between the attitude of boys taught by male teachers and that of boys taught by female teachers

Table 1. Attitude of boys taught by male teachers and that of boys taught by female teachers

\begin{tabular}{|c|c|c|c|c|c|c|c|}
\hline & Teacher Gender & $\mathrm{N}$ & $\bar{\chi}$ & $\mathrm{SD}$ & $\mathrm{t}$-calculated & $\mathrm{df}$ & $\mathrm{t}$-critical \\
\hline \multirow{2}{*}{ Attitude of Boys to Schooling } & Male Teacher & 100 & 32.96 & 4.97 & $7.78^{*}$ & 198 & 1.97 \\
\cline { 2 - 9 } & Female Teacher & 100 & 27.76 & 4.47 & & & \\
\hline
\end{tabular}

*Significant at $\mathrm{p}<.05$

Ho 2. There is no significant difference between the attitude of girls taught by male teachers and that of girls taught by female teachers. 
Table 2. Attitude of girls taught by male teachers and that of girls taught by female teachers

\begin{tabular}{|c|c|c|c|c|c|c|c|}
\hline & Teacher Gender & $\mathrm{N}$ & $\bar{\chi}$ & $\mathrm{SD}$ & $t$-calculated & $d f$ & $t$-critical \\
\hline \multirow{3}{*}{ Attitude of Girls to Schooling } & Male Teacher & 100 & 33.07 & 4.65 & $7.27 *$ & 198 & 1.97 \\
\cline { 2 - 9 } & Female Teacher & 100 & 27.95 & 5.29 & & & \\
\hline
\end{tabular}

*Significant at $\mathrm{p}<.05$

Ho 3. There is no significant difference between the attitude of boys taught by male teachers and that of girls taught by male teachers.

Table 3. Attitude of boys taught by male teachers and that of girls taught by male teachers

\begin{tabular}{|c|c|c|c|c|c|c|c|}
\hline & Pupil Gender & $\mathrm{N}$ & $\bar{\chi}$ & $\mathrm{SD}$ & $t$-calculated & $d f$ & $t$-critical \\
\hline \multirow{2}{*}{ Attitude to Schooling } & Boys & 100 & 32.96 & 4.97 & 0.16 & 198 & 1.97 \\
\cline { 2 - 9 } & Girls & 100 & 33.07 & 4.65 & & & \\
\hline
\end{tabular}

$p<.05$

Ho 4. There is no significant difference between the attitude of boys taught by female teachers and that of girls taught by female teachers.

Table 4. Attitude of boys taught by female teachers and that of girls taught by female teachers

\begin{tabular}{|c|c|c|c|c|c|c|c|}
\hline & Pupil Gender & $\mathrm{N}$ & $\bar{\chi}$ & $\mathrm{SD}$ & $t$-calculated & $d f$ & $t$-critical \\
\hline \multirow{2}{*}{ Attitude to Schooling } & Boys & 100 & 27.76 & 4.47 & 0.27 & 198 & 1.97 \\
\cline { 2 - 9 } & Girls & 100 & 27.95 & 5.29 & & & \\
\hline
\end{tabular}

$\mathrm{p}<.05$

In Table 4 , the calculated value of the t-statistics (0.27) is less than the critical value of the t-statistics. Based on the decision rule $(\mathrm{p}<.05)$, the fourth hypothesis was upheld. A detailed look at the analysis shows that both boys and girls taught by female teachers had a mean score of 28 on the PASQ, if the computed mean scores(27.76 for boys and 27.95 for girls) were to be rounded up to the nearest whole number. This showed that, as hypothesised, there is no significant difference in the attitudes of boys and girls taught by female teachers to schooling.

\section{Discussion}

Analysis of the first hypothesis showed that there is a significant difference in the attitude of boys taught by male teachers and that of boys taught by female teachers. This is an indication that, in the population under investigation, boys taught by male teachers have a more positive attitude to schooling than boys taught by female teachers.

Previous studies in other populations, such as those cited by Smith [21] presented evidence that a strong link exists between the gender of the teacher and the academic performance of the pupils. Also, Mallam [17], focusing on students' attitude to mathematics, found that female students taught by female teachers had a significantly different attitude towards mathematics from female students taught by male teachers. Similar results were obtained by Lee and Lockheed [14], who found that female students taught by female teachers had a more positive attitude towards mathematics than female students taught by male teachers. What makes the result of the second hypothesis of this study very interesting is that female pupils taught by male teachers had a more positive attitude to schooling than female pupils taught by female teachers.

These results raised a 3rd and 4th Research Questions viz; Do boys taught by male teachers have more positive attitudes to schooling than girls taught by male teachers? Do boys taught by female teachers have more positive attitudes towards schooling than girls taught by female teachers? These questions were converted to hypotheses 3 and 4 which were also tested based on the same research data. The results obtained led to the retention of both the 3rd and 4th null hypotheses. As presented in Tables 3 and 4, it was observed that pupils (both boys and girls) taught by male teachers had a consistently overall positive attitude to schooling whereas pupils (both boys and girls) taught by female teachers showed a consistently negative (less positive) attitude to schooling.

This finding is in concert with the submissions of $\mathrm{Li}$ [15]. $\mathrm{Li}$ found that where teacher-student gender interaction existed, it influenced student-teacher rating behaviour such that in some cases certain variables influenced a higher rating for teachers of the opposite gender and in other cases a preference for teacher of the same gender. Indisputably, the findings of the current study pose a few significant concerns for future researches. First and foremost, though not captured within its purview, the study shows that beyond or in relation to teacher gender, there are other significant variables that influence students' teacher-gender 
rating and preference. Secondly, in view of the alarming discrepancy in the proportion of male and female teachers in primary schools in the study region, it is worrisome that $86.87 \%$ of the teachers being female engender less positive attitudes to schooling in the pupils. Therefore, like Li [15] proposed, it is imperative to examine teacher variables, beyond teacher gender, based on which students rate teachers of the opposite gender more highly.

Moreover, the current research shows that besides teacher demographic characteristics, there could be other teacher variables that induced the attitude pool towards male teachers and the observed difference towards female teachers. Until such variables are identified, policy concerns would necessarily focus on bridging the gap in teacher gender proportion in primary schools as a matter of urgency.

\section{Conclusion}

This study was an effort to examine the influence of teacher gender on the overall attitude of primary school pupils to schooling in Uyo metropolis of Akwa Ibom State. The study was informed by current concerns over teacher-gender imbalance amidst widespread research reports correlating teacher-gender with students' performance and students' attitude to schooling or certain school subjects. From the findings of this study, the researchers here conclude that teacher gender has significant influence on the attitude of pupils to schooling. The researchers further conclude that in their study population, male teacher gender has the most persuasive influence on pupils' attitudes to schooling whilst female teacher gender is observed to generally relate with less positive attitude to schooling among the pupils. Finally, the researchers submit that teacher variable (teacher gender in this case) is the most significant predictor of students' attitude to schooling whilst student variable (student gender in this case) has less decided influence on students' attitudes to schooling.

\section{Recommendations}

The researchers therefore make the following recommendations:

1. More males should be encouraged to join the teaching profession, especially at the pre-primary and primary levels. This can be achieved through school career counselling programmes aimed at helping males recognise that they too can be teachers of pupils in primary schools and that primary education is not a feminine reserve.

2 . The government should encourage the enlistment of males both in teacher education and teacher employment.

3. The government should provide loans, grants and scholarships to males who would be aspiring to become primary school teachers in order to make the job more attractive to male aspirants.
4. Teachers' associations and school authorities should make serious efforts to improve upon the image of teachers in the primary schools in order to make the job more attractive to the male folks.

5. Researchers in education should conduct further studies on teacher gender and students attitude to schooling. Such future studies should aim to explain further why male teachers tend to engender more positive attitudes to schooling among pupils than female teachers.

\section{REFERENCES}

[1] Adesokan, G. O. (2002). Students' attitudes and gender as determinants of performance in JSS 1 Integrated Science.Unpublished B.Ed project.University of Ado Ekiti.

[2] Alao, E. O. (1988). Attitudes of secondary school students to the Basic Sciences in selected Local Government Areas of Oyo State. Doctoral Dissertation, University of Ife, Ile-Ife.

[3] Amoo, S. A. (2002). Analysis of problems encountered in teaching and learning of mathematics in secondary schools. ABACUS: The Journal of the Mathematical Association of Nigeria, 27 (1), 130-135.

[4] Amoo, S. R. \& Rahman, M. A. (2004). Secondary school students' attitudes to learning mathematics in the world of Information Technology: Implications for mathematics teachers and teacher preparation. In M.A.G. Akale (ed.). Proceedings of the STAN 45th Annual Conference held at Abuja 19th-23rd August, pp. 179-182.

[5] Bolaji, C. (2005). A study of factors influencing students' attitude towards mathematics in the junior secondary schools.Mathematics Teaching in Nigeria. Retrieved on 21st October, 2010, from http://www.ncsu.edu/ncsu/acrn/bolajim. html.

[6] Bursterin, L. (1992). The analysis of multilevel data in educational research and evaluation. Review of Research in Education, 8, 158-223.

[7] Dee, T. S. (2005a). A teacher like me: Does race, ethnicity, or gender matter? American Economic Review, 95(2): 158-165. Doi: $10.1257 / 000282805774670446$.

[8] Dee, T. S. (2005b). Teachers and the gender gap in school achievement. NBER Working Papers 11660.

[9] Feldman, R. S. (2000). Essentials of Understanding Psychology (4thed.). Boston: McGraw-Hill Higher Education.

[10] Gibbons, S., Kimmel, H. \& O’Shea, M. (1997). Changing teacher behaviour through staff development: Implementing the teaching and content standard in science. School Science and Mathematics, 96(6), 302-310.

[11] Johnson, D. W. (1979). Educational Psychology. Englewood Cliffs, New Jersey: Prentice-Hall, Inc.

[12] Kinniard, J. (2010). Does attitude impact academic achievement? Unpublished Master's Research Project, College of Education, Ohio University. Retrieved on 24th December, 2011, from 
http://www.cehs.ohio.edu/gfx/media/pdf/kinniard.pdf.

[13] Krieg, J. M. (2005, April 12). Student gender and teacher gender: What is the impact on high stakes test scores? Current issues in education (Online), 8(9).Retrieved on 17th May, 2011 , http://www.cie.asu.edu/volume8/number9/index.html.

[14] Lee, B. E. \& Lockheed, M. E. (1990). The effects of single-sex schooling on achievement and attitudes in Nigeria.Comparative Education Reviews, 34(2), 209-231.

[15] Li, Q. (undated). Teachers' beliefs and gender differences in mathematics: A review. Retrieved on 17th May, 2011, from people.ucalgary.ca/ qinli/publication/Teachers-beliefs.

[16] Liddell, M. J. \& Davidson, S. K. (2004) Student attitudes and their academic performance: Is there any relationship? Med. Teach., 26(1), 52-56. Retrieved on 24th December, 2011, from http://www.ncbi.nlm.nih.gov/pubmed/14744695.

[17] Mallam, W. A. (1993). Impact of school-type and sex of the teacher and female students' attitudes toward mathematics in Nigerian secondary schools.Educational Studies in Mathematics, 24, 223-229.

[18] Manoah, S. A., Indoshi, F. C. \& Othuon, L. O A. (2011).
Influence of attitude and performance of students in mathematics curriculum. Educational Research, 2(3), 965-981. Retrieved on 23rd December, 2011, from http://www.interesjournals.org/ER.

[19] Mullis, I. V. S. (2000). TIMSS 1999 International Mathematics report: Findings from IEA's repeat of the Third International Mathematics and Science Study at Eighth Grade. Chestnut Hill, MA: Boston College.

[20] Olatoye, R. A. (2002). A causal model of school factors as determinants of science achievement in Lagos State secondary schools. Unpublished Ph.D thesis, University of Ibadan, Ibadan.

[21] Smith, S. (2004). Teaching and the gender imbalance: Do we need more mates? Retrieved on 17th May, 2011, from www.teachers.ash.org.au/bce/Research\%20report.htm.doc.

[22] SUBEB, (2013). Student population in Akwa Ibom State. State Universal basic Education Board, Statistics Department.

[23] Tandoc, N. L. (2006). Attitude and performance in mathematics of University of Baguio High School students.UB Research Journal, 30 (1). Retrieved on 23rd December, 2011, from http://ubaguio.edu/reserach/index.php? option $=$ com_ content\&view $=$ catego. 